\title{
AMPLIFIKASI GEN 16S-rRNA BAKTERI TERMOFILIK DARI SUMBER AIR PANAS, GUNUNG PANCAR BOGOR
}

\author{
Suryani, Laksmi Ambarsari, Efi Sanfitri Harahap \\ Departemen Biokimia, FMIPA-IPB \\ Gedung Fapet, Lantai 5, Wing 5, \\ Jl.Agatis, Kampus IPB Darmaga, Bogor, 16680 \\ Email : ani3110@yahoo.com
}

\begin{abstract}
Exploration of thermophilic bacteria that produce thermostable enzyme is most useful in application for enzyme base industrial. The aim of of this research is to isolate and amplificate the 16S-rRNA gene from thermophilic bacteria isolate at hotspring, Mount of Pancar, Bogor. The research steps consist of bacteria isolation, chromosomal DNA extraction, and amplification of 16S-rRNA gene. The water sample as source for bacteria was collected from four cauldrons. Temperature and $\mathrm{pH}$ for each cauldron are red cauldron $75-80^{\circ} \mathrm{C}, \mathrm{pH} 7$; black cauldron $55^{\circ} \mathrm{C}, \mathrm{pH} 7$; white cauldron $57^{\circ} \mathrm{C}, \mathrm{pH} 7$; and saline cauldron $25^{\circ} \mathrm{C}, \mathrm{pH} 6$, respectively. The bacteria were cultivated at Luria Bertani (LB) and Thermus media. The chromosomal DNA have been extracted. Gene amplification of 16 S-rRNA have been carried out by using universal primer (Bac F1 and Uni $\mathrm{B} 1)$. The size of amplicon is $\pm 1.5 \mathrm{~kb}$.
\end{abstract}

Keywords : thermophilic bacteria, chromosomal DNA extraction, amplification of 16S-rRNA gene,

\section{PENDAHULUAN}

Indonesia memiliki keragaman ekosistem yang sangat tinggi sehingga sangat potensial sebagai sumber eksplorasi berbagai jenis mikroba. Keragaman hayati mikroba ini perlu digali secara sistematis dan mendalam melalui eksplorasi sebanyak mungkin mikroba dari lingkungan yang ekstrim. Salah satu lingkungan ekstrim yang dimiliki Indonesia adalah daerah vulkanik dengan keragaman mikroba yang memiliki kemampuan tumbuh pada kondisi ekstrim seperti suhu, $\mathrm{pH}$, dan konsentrasi garam yang tinggi ${ }^{[1]}$.

Pada daerah vulkanik terdapat jenis bakteri yang tumbuh dalam kondisi ekstrim, seperti bakteri termofilik yang berpotensi menghasilkan enzim termostabil. Bakteri termofilik mampu bertahan dan berkembang biak pada suhu tinggi. Hal ini disebabkan karena kandungan enzim, ribosom, protein, dan konstituen-konstituen lainnya lebih stabil dibandingkan bakteri mesofil.
Hal lainnya karena membran lipid bakteri termofil kaya akan asam lemak jenuh sehingga membentuk ikatan hidrofobik yang jauh lebih kuat $^{[2]}$. Pemanfaatan enzim termostabil di bidang industri berbasis enzim sangat menguntungkan karena dapat meminimalkan resiko terjadinya kontaminasi, meningkatkan laju transfer massa, menurunkan viskositas sehingga dapat memperkecil biaya operasional dan meningkatkan produktifitas.

Hingga saat ini, identifikasi mikroba tersebut belum dilakukan secara menyeluruh, karena hanya bergantung pada isolasi dari kultur murni yang diikuti dengan analisis sifat-sifat fisiologi dan biokimianya. Kondisi ini disebabkan, karena sebagian besar bakteri belum dapat dikultivasi ${ }^{[3]}$. Alasan kegagalan kultivasi ini disebabkan nutrisi dan kondisi pertumbuhan yang tidak sesuai, sel-sel yang tidak dapat dikulturkan dan sifat intrinsik dari banyak organisme ${ }^{[4]}$.

Salah satu pendekatan yang dapat dilakukan selain kultivasi adalah pendekatan molekuler. Aplikasi molekuler untuk menganalisis 
keragaman bakteri melalui analisis gen 16SrRNA dapat mengatasi kesulitan untuk kultivasi bakteri. Gen 16S-rRNA sesuai untuk identifikasi bakteri karena gen ini terdapat pada semua organisme. Gen penyandi 16SrRNA mempunyai daerah berbeda yang terdiri atas sekuen gen yang konservatif dan berguna untuk mengkonstruksi pohon filogenik yang lebih diskriminatif. Sekuen gen penyandi 16SrRNA dari berbagai organisme yang sudah dapat dikulturkan maupun yang tidak dapat dikulturkan telah dibuat dalam bentuk database. Terdapat lebih dari 4000 sekuen yang terdapat pada database 16S-rRNA dan mencakup sekitar 1800 spesies yang jumlahnya terus bertambah ${ }^{[5]}$.

Dalam penelitian ini telah dilakukan isolasi DNA dari komunitas bakteri termofilik dengan metoda kultivasi, kemudian mengamplifikasi gen 16S-rRNA dari DNA kromosom yang diperoleh. Amplikon yang diperoleh dapat dianalisis lebih lanjut untuk mengidentifikasi bakteri yang berhasil diisolasi. Identifikasi ini menjadi sangat penting mengingat besarnya potensi yang dimiliki oleh bakteri termofilik terutama enzim-enzim termostabil yang dimilikinya.

Tujuan penelitian ini untuk mengisolasi dan mengamplifikasi gen 16S-rRNA isolat bakteri yang ada di sumber air panas, kawasan wisata Gunung Pancar Bogor. Keragaman genetik bakteri termofilik dari sumber isolasi dapat diketahui melalui amplifikasi gen penyandi 16S-rRNA, kemudian dilanjutkan dengan melakukan analisis tehadap amplikon. Bakteri termofilik hasil penelitian ini diharapkan memiliki stabilitas serta aktifitas tinggi sehingga potensial untuk digunakan pada industri-industri berbasis enzim.

\section{METODOLOGI}

\section{Pembuatan Media Thermus dan Luria Bertani (LB)}

Bahan-bahan yang digunakan untuk membuat media Thermus terdiri atas $0,1 \mathrm{~g}(\mathrm{NH})_{4} \mathrm{SO}_{4}$; $0,25 \mathrm{~g} \mathrm{MgSO}_{4} .7 \mathrm{H}_{2} \mathrm{O} ; 0,125 \mathrm{~g} \mathrm{CaCl}_{2} .2 \mathrm{H}_{2} \mathrm{O} ; 0,3$ $\mathrm{g} \mathrm{KH}_{2} \mathrm{PO}_{4} ; 1 \mathrm{~g} \mathrm{NaCl} ; 2 \mathrm{~g}$ yeast extract dan $4 \mathrm{~g}$ pepton. Untuk pembuatan media Luria Bertani (LB), sebanyak $1,25 \mathrm{~g}$ yeast extract, $0,5 \mathrm{~g}$
$\mathrm{NaCl}$, dan $0,5 \mathrm{~g}$ tripton ditimbang. Semua bahan dilarutkan dalam akuades hinggá volumenya tepat $1000 \mathrm{~mL}$. Selanjutnya media tersebut disterilisasi dengan autoklaf pada $121^{\circ} \mathrm{C}, 1 \mathrm{~atm}$ selama 15 menit.

\section{Isolasi Bakteri}

Sampel air kawah ditampung dalam jerigen steril, kemudian dikulturkan ke dalam media Thermus dan LB dan diinkubasi selama 2 hari pada suhu $55^{\circ} \mathrm{C}$.

\section{Isolasi DNA Kromosom}

Kultur bakteri yang telah tumbuh disegarkan dalam media Thermus dan LB, lalu diinkubasi selama 1 hari. Pelet (sel) diperoleh dengan cara disentrifugasi pada $2000 \mathrm{~g}$ selama 20 menit. Pelet sel yang diperolah diresuspensi dalam buffer Tris $\mathrm{HCl}, \mathrm{pH}$ 8,0 yang mengandung EDTA, kemudian suspensi sel dibekukan pada $-20^{\circ} \mathrm{C}$. Larutan lisozim $(10 \mathrm{mg} / \mathrm{mL}$ 0,25 M Tris $\mathrm{HCl}, \mathrm{pH} 8,0$ ) kemudian ditambahkan ke dalam sel yang telah beku dan dicairkan dalam water bath pada suhu ruang. Sel yang telah cair, dibiarkan dalam es selama 45 menit. Selanjutnya ditambahkan buffer STEP $(0,5 \%$ SDS, $50 \mathrm{mM}$ Tris $\mathrm{HCl}, \mathrm{pH}$ 7,5; 0,4 M EDTA) dan diaduk serta dipanaskan pada suhu $50^{\circ} \mathrm{C}$ selama 60 menit. Kemudian buffer tris fenol ditambahkan ke dalam suspensi sel, lalu dikocok dengan perlahan selama 5 menit. Suspensi tersebut kemudian disentrifugasi pada $1000 \mathrm{~g}$ selama 15 menit. Supernatan yang diperoleh dipindahkan ke dalam tabung eppendorf baru. Supernatan tersebut mengandung DNA kromosom dan disimpan pada suhu $-20^{\circ} \mathrm{C}$ untuk keperluan analisis.

\section{Elektroforesis Gel Agarosa}

DNA kromosom dielektroforesis pada agarosa $1 \%$ dengan menggunakan metode Laemli.

\section{Amplifikasi Gen Parsial 16S-rRNA}

Campuran total reaksi PCR $(25 \mu \mathrm{L})$ mengandung buffer PCR $1 \times, 4 \mathrm{mM}$ dNTP, pasangan primer Bac $\mathrm{F} 1$ dan Uni B1 masingmasing 100 pmol, 2 unit Taq DNA polymerase dan $1 \mu \mathrm{L}$ DNA template. Proses amplifikasi menggunakan metode touchdown. Siklus pertama menggunakan suhu annealing 
tertinggi, suhu annealing berikutnya turun dua derajat secara bertahap. Tahap denaturasi awal pada suhu $94^{\circ} \mathrm{C}$ selama 5 menit dilanjutkan dengan satu siklus PCR dengan suhu denaturasi $94^{\circ} \mathrm{C}$ selama 45 detik, suhu annealing $53^{\circ} \mathrm{C}$ selama 45 detik dan pemanjangan pada $72^{\circ} \mathrm{C}$ selama 3 menit, kombinasi suhu PCR berikutnya sama, yang berbeda hanya suhu annealing-nya yaitu $50^{\circ} \mathrm{C}$, $47^{\circ} \mathrm{C}$ dan $45^{\circ} \mathrm{C}$. Suhu annealing terakhir diulang sebanyak 20 siklus. Selanjutnya adalah tahap akhir pemanjangan pada $72^{\circ} \mathrm{C}$ selama 7 menit dan diinkubasi pada $4^{\circ} \mathrm{C}$ hingga proses berikutnya.

\section{HASIL DAN PEMBAHASAN}

Suhu dan pH Lingkungan pada Kawah Merah, Hitam, Asin, dan Putih

Pengambilan sampel dilakukan di kawasan wisata air panas Gunung Pancar yang terletak di daerah Sentul, Bogor. Sampel diambil dari 4 lokasi, yaitu Kawah Merah, Kawah Hitam, Kawah Putih dan Kawah Asin. Pengambilan sampel dilakukan pada bagian tengah dan di bawah permukaan kawah. Hal tersebut bertujuan untuk mendapatkan bakteri dengan suhu tinggi yang maksimal.

Hasil pengamatan terhadap sampel air yang terdapat pada kawah gunung Pancar memiliki suhu yang bervariasi (Tabel 1). Suhu air pada Kawah Merah $75-80^{\circ} \mathrm{C}$ dan memiliki pH 7. Warna kawahnya merah, dan kedalamannya lebih dari lima meter. Kawah Merah memiliki mata air, warna airnya kecoklatan dan kedalamannya mencapai satu meter. Sedangkan suhu air pada Kawah Hitam $55^{\circ} \mathrm{C}$ dengan $\mathrm{pH}$ 7. Pada Kawah Hitam terdapat tujuh mata air dengan warna airnya bening. Suhu air pada Kawah Putih $57^{\circ} \mathrm{C}$ dan memiliki $\mathrm{pH}$ 7. Keadaan Kawah Putih mirip dengan keadaan Kawah Hitam, bedanya Kawah Putih dilingkupi oleh pelindung. Suhu air pada Kawah Asin adalah $25^{\circ} \mathrm{C}$ dengan $\mathrm{pH} 6$.

\section{DNA Kromosom Hasil Isolasi}

Isolasi DNA merupakan tahap awal untuk melakukan proses PCR. DNA kromosom diisolasi dari bakteri yang dikultivasi pada media Thermus dan LB. Hasil isolasi diperoleh delapan DNA kromosom yaitu DNA kromosom yang dikultivasi pada media Thermus dan LB yang masing-masing berasal dari kawah hitam, kawah merah, kawah putih, dan kawah asin. Untuk mengetahui DNA kromosom tersebut dilakukan elektroforesis agarose. Hasil elektroforesis menunjukkan bahwa semua sampel DNA kromosom telah berhasil diisolasi hal ini ditunjukkan dengan adanya pita-pita yang muncul pada gel agarose (Gambar 1).

Pengukuran secara kuantitatif terhadap DNA tidak dilakukan pada percobaan ini, karena DNA yang dipakai sebagai template pada proses PCR tidak memerlukan DNA dengan tingkat kemurnian yang tinggi ${ }^{[6]}$. Pengukuran konsentrasi DNA yang diperoleh dilihat dibawah sinar UV, kemudian konsentrasi DNA diperhitungkan dengan cara membandingkan ketebalan pita DNA dengan marker yang telah diketahui konsentrasinya. Untuk mendapatkan konsentrasi DNA yang lebih pekat maka DNA kromosom yang sudah diekstraksi kemudian dipekatkan kembali dengan cara pengendapan menggunakan etanol.

Tabel 1. Suhu dan pH Air dari Kawah Gunung Pancar

\begin{tabular}{cccc}
\hline Nama Kawah & Suhu $\left({ }^{\circ} \mathrm{C}\right)$ & $\begin{array}{c}\mathrm{pH} \\
\text { in situ }\end{array}$ & $\begin{array}{c}\mathrm{pH} \\
\text { ex situ }\end{array}$ \\
\hline Merah & 80 & 7 & 6.88 \\
Hitam & 55 & 7 & 7.00 \\
Putih & 57 & 7 & 7.22 \\
Asin & 25 & 6 & 5.85 \\
\hline
\end{tabular}




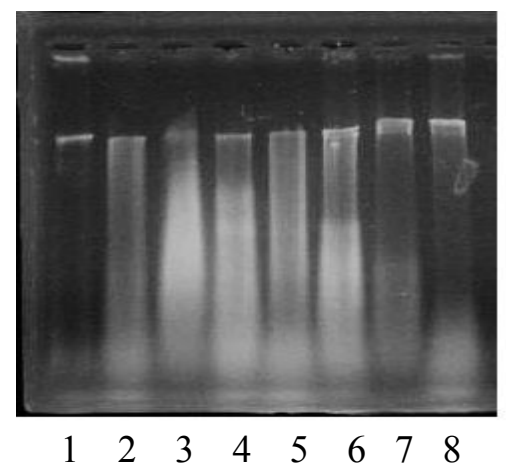

Gambar 1. Elektroforegram DNA kromosom. (1) Kawah Hitam Thermus; (2) Kawah Hitam LB; (3) Kawah Merah Thermus; (4) Kawah Merah LB; (5) Kawah Putih LB; (6) Kawah Putih Thermus; (7) Kawah Asin LB; dan (8) Kawah Asin Thermus

\section{Amplikon Gen 16S-rRNA}

Proses amplifikasi gen 16S-rRNA pada DNA kromosom dari isolat bakteri dilakukan dengan menggunakan primer Bac F1 dan Uni B1 dengan metode touchdown, yaitu metode PCR dengan modifikasi suhu dalam setiap siklusnya untuk mencegah annealing primer pada daerah yang nonspesifik. Suhu annealing pada template DNA menentukan kespesifikan amplikon, namun juga menyulitkan primer untuk menempel.

Dalam penelitian ini touchdown PCR dilakukan dalam beberapa suhu annealing yang bertingkat, yaitu dari suhu yang tinggi ke suhu yang rendah. Pada siklus annealing yang pertama digunakan suhu yang tinggi, dalam percobaan ini digunakan suhu $53^{\circ} \mathrm{C}$ selanjutnya dengan cara mengatur program yang terdapat pada mesin PCR suhu annealing pada setiap siklus diturunkan dua derajat hingga siklus yang terakhir suhu annealingnya $44^{\circ} \mathrm{C}$. Dengan metode ini diharapkan primer dapat menempel pada daerah yang spesifik sehingga diperoleh amplikon sesuai dengan analisis. Untuk mendapatkan hasil yang optimal, maka dalam penelitian ini amplifikasi dilakukan dalam empat kombinasi suhu PCR Kombinasi suhu I dilakukan dengan mengatur suhu annealing pada siklus mulai dari $53^{\circ} \mathrm{C}$ hingga $44^{\circ} \mathrm{C}$, suhu annealing turun dua derajat untuk setiap 7 siklus. Kombinasi suhu II dilakukan seperti sebelumnya dengan jumlah siklus yang sama hanya pada suhu $44^{\circ} \mathrm{C}$ siklusnya diperbanyak menjadi 20 siklus.
Hasil yang diperoleh dari percobaan yang telah dilakukan menunjukkan bahwa proses touchdown PCR dengan kombinasi suhu I belum menghasilkan amplikon. Hal ini disebabkan karena faktor suhu annealing serta jumlah siklus pada tiap-tiap tahap belum optimum. Suhu annealing yang tinggi cukup hanya untuk satu siklus dan diharapkan diperoleh amplikon yang spesifik, dan siklus terbanyak dilakukan pada suhu terendah untuk memudahkan annealing primer pada template. Oleh karena itu dilakukan proses amplifikasi dengan menggunaan kombinasi suhu II dengan perubahan pada suhu annealing dan jumlah siklus.

Hasil yang diperoleh menunjukkan adanya pita pada sampel DNA yang berasal dari Kawah Hitam yang ditumbuhkan dalam media LB, namun pita yang dihasilkan masih tipis (tidak didokumentasi), sehingga dilakukan percobaan dengan kombinasi suhu III yang menggunakan template DNA dari Kawah Hitam dengan media LB. Amplikon yang diperoleh pada kondisi dengan kombinasi suhu II dilakukan PCR ulang dengan kondisi kombinasi suhu III. Perbedaan kombinasi suhu II dengan kombinasi suhu III adalah satu kombinasi suhu annealing dihilangkan, yaitu suhu annealing $44^{\circ} \mathrm{C}$.

Hasil percobaan menunjukkan bahwa proses PCR yang menggunakan template DNA kromosom secara langsung tidak menunjukkan adanya amplifikasi, sedangkan PCR yang dilakukan dengan menggunakan template hasil amplifikasi (re-PCR) menunjukkan pita DNA 
yang lebih tebal dengan ukuran sekitar $1,5 \mathrm{~kb}$, hasil amplifikasi terlihat pada elektroforegram pada kolom 2 (Gambar 2). Namun masih terdapat pita DNA yang berada pada daerah di atas 1,5 kb. Hal ini menunjukkan annealing primer yang belum spesifik, kemungkinan disebabkan oleh suhu annealing yang terlalu rendah. Oleh karena itu, kembali dilakukan PCR dengan kombinasi suhu IV yaitu dengan menaikkan suhu annealing terendahnya menjadi $45^{\circ} \mathrm{C}$. Namun demikian dapat disimpulkan bahwa kondisi touchdown PCR dengan kombinasi suhu annealing III telah berhasil mengamplifikasi.

Ukuran DNA amplikon yang diperoleh telah sesuai dengan penelitian yang dilakukan sebelumnya ${ }^{[7]}$ dengan menggunakan primer yang sama yaitu $1,5 \mathrm{~kb}$. Menurut Bottger ${ }^{[5]}$ gen penyandi 16S-rRNA mempunyai daerah berbeda yang terdiri atas sekuen gen yang konservatif dan berguna untuk mengkonstruksi pohon filogenik yang lebih diskriminatif. 16SrRNA merupakan kerangka penyusun ribosom yang peranannya sangat penting di dalam sintesis protein dan dimiliki oleh semua sel sehingga semua organisme dapat dibandingkan secara setara ${ }^{[8]}$. Database sekuen gen penyandi 16S-rRNA dari berbagai organisme yang sudah dapat dikulturkan maupun yang tidak dapat dikulturkan telah dibuat databasenya. Tujuan utama pendataan ini adalah untuk mengukur secara tepat hubungan evolusioner di antara organismeorganisme, disamping dapat menjadi katalog untuk keragaman mikroba.

Untuk percobaan selanjutnya dengan kondisi PCR kombinasi suhu IV, template yang digunakan adalah DNA kromosom dari Kawah Hitam dan kawah asin media Thermus, serta Kawah Hitam dan kawah asin media LB. Pemilihan sampel ini didasarkan pada kualitas pita DNA hasil presipitasi etanol.

Hasil elektroforesis menunjukkan adanya pita DNA pada daerah sekitar $1,5 \mathrm{~kb}$ untuk sampel DNA kromosom dari Kawah Hitam dengan media Thermus dan Kawah Asin dengan media LB. Hanya terdapat satu pita DNA, hal ini menunjukkan bahwa annealing primer pada DNA tempelate sudah spesifik (Gambar 3).

Tahap selanjutnya pada penelitian ini adalah mengamplifikasi sampel-sampel dari kawah lain dengan kondisi PCR yang optimum. Konsentrasi DNA diukur terlebih dahulu sebelum diamplifikasi untuk menentukan jumlah DNA yang ditambahkan pada campuran reaksi PCR. Hasil pengukuran, diperoleh konsentrasi DNA dari isolat Kawah Hitam Thermus $387 \mu \mathrm{g} / \mathrm{mL}$ dan Asin LB 489 $\mu \mathrm{g} / \mathrm{mL}$. Perbandingan absorban DNA pada panjang gelombang 260 dengan absorban DNA pada panjang gelombang 280 menunjukkan kemurnian DNA kromosom yang diperoleh. Kemurnian DNA dinilai baik jika mempunyai nilai perbandingan $\geq 1,7$; hal ini berarti perbandingan antara DNA dengan protein adalah 1,7:1. Hasil pengukuran yang menunjukkan nilai tersebut adalah isolat dari Kawah Hitam Thermus dan isolat dari Kawah Asin LB (Tabel 2). Hal ini juga menunjukkan bahwa isolasi DNA kromosom telah berhasil dilakukan.

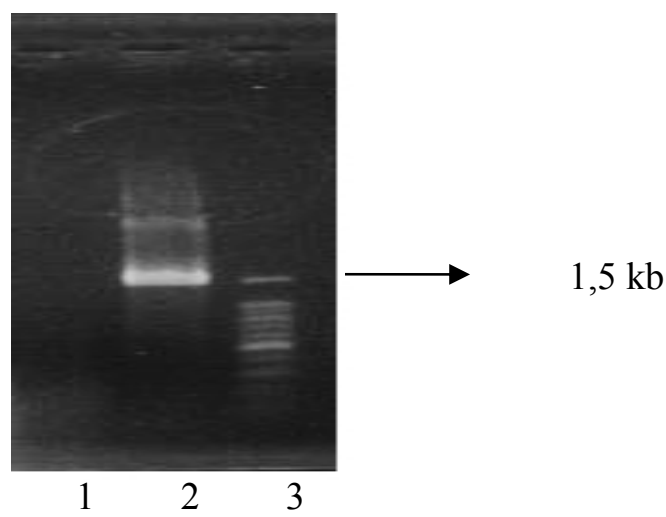

Gambar 2. Elektroforegram gel agarosa hasil amplifikasi kombinasi III suhu PCR; (1) DNA kromosom Kawah Hitam LB; (2) Re-PCR 16S-rRNA; (3) marker 0,1 kb 
Hasil elektroforesis menunjukkan bahwa DNA kromosom yang diampilifikasi menggunakan primer Bac F1 dan Uni B1 merupakan gen 16 S-rRNA yang memiliki ukuran sekitar 13001500 bp. Amplikon yang dihasilkan pada PCR terakhir terlihat lebih tebal. Hal ini membuktikan bahwa komposisi reagen-reagen pada proses ini dalam kondisi optimal. Selain itu, pita amplikon juga tidak smearing yang menunjukkan kespesifikannya. Hal di atas menunjukkan bahwa proses PCR berjalan dengan baik.

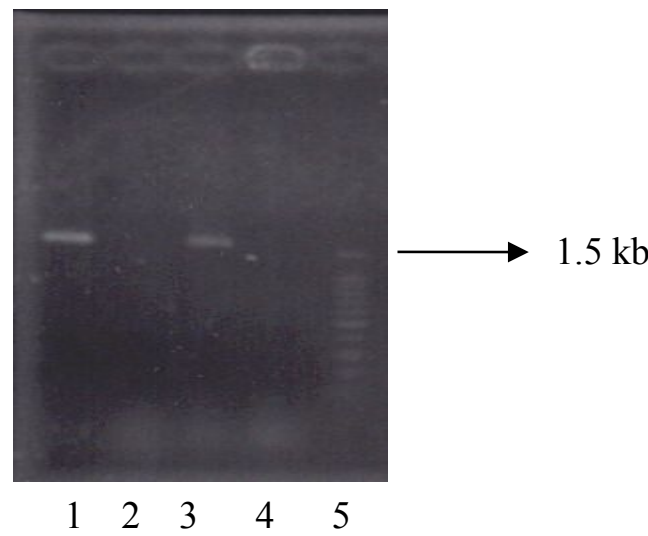

Gambar 3. Elektroforegram gel agarosa hasil amplifikasi kombinasi suhu IV; (1) DNA kromosom Kawah Hitam Thermus; (2) DNA kromosom Kawah Hitam LB; (3) DNA kromosom Kawah Asin LB; (4) DNA kromosom Kawah Asin Thermus; (5) marker 0,1 kb

Tabel 2. Konsentrasi DNA

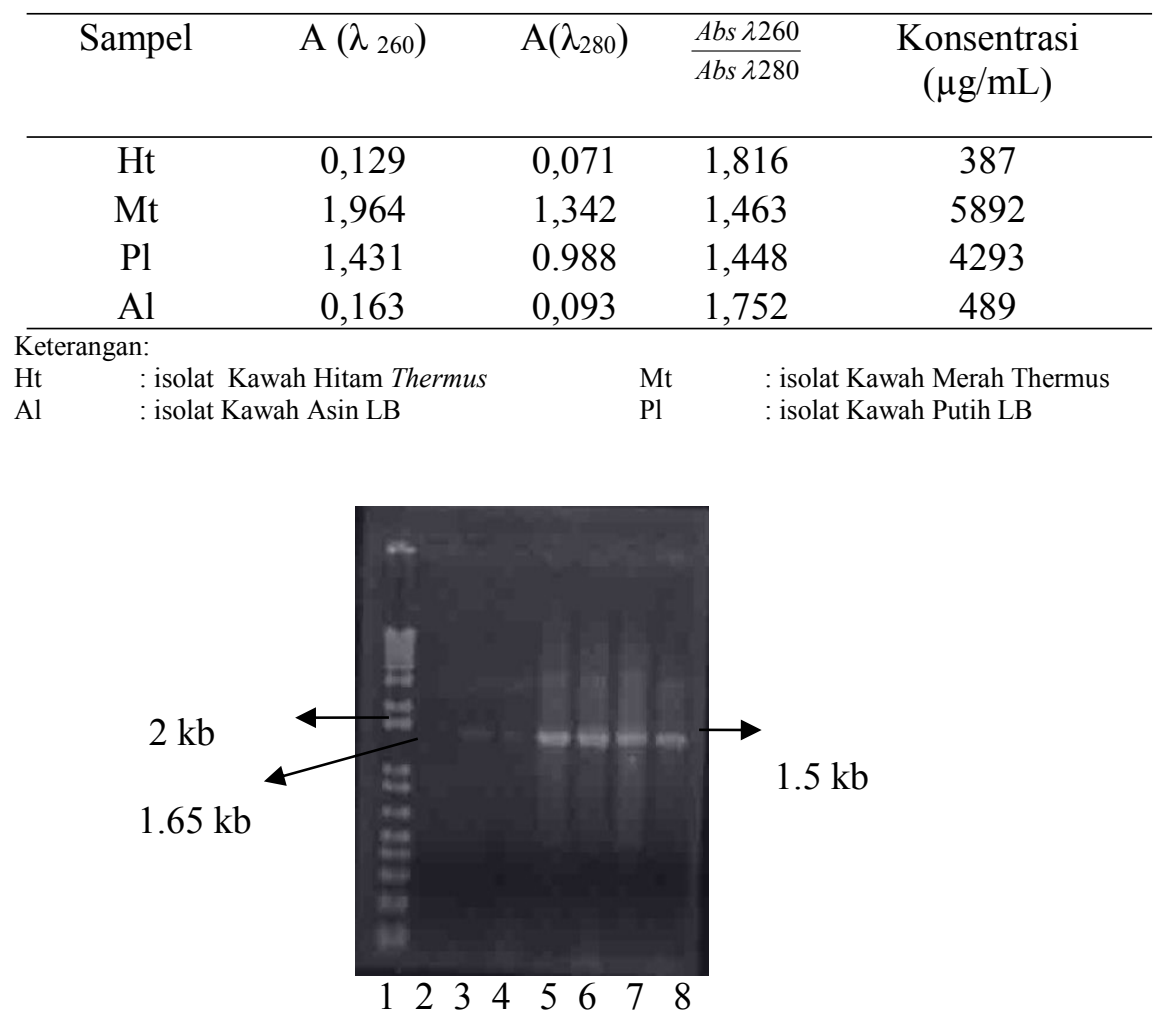

Gambar 4. Elektroforegram amplikon;(1) Marker $1 \mathrm{~kb}$; (2) isolat Kawah Hitam Thermus PCR kombinasi suhu III; (3) isolat Kawah Hitam Thermus PCR kombinasi suhu IV; (4) isolat Kawah Asin Thermus kombinasi suhu IV;(5) isolat Kawah Hitam Thermus kombinasi suhu IV;(6) isolat Kawah Merah Thermus kombinasi suhu IV;(7) isolat Kawah Putih LB kombinasi suhu IV;(8) isolat Kawah Asin LB kombinasi suhu IV 


\section{KESIMPULAN}

Bakteri yang berasal dari kawah merah, kawah hitam, kawah putih dan kawah asin pada Gunung Pancar, Bogor dapat diisolasi dan tumbuh dengan baik pada media Thermus dan LB dan berhasil diisolasi DNA kromosomnya. Amplifikasi fragmen 16 S-rRNA berhasil dilakukan dari isolat bakteri berasal dari Kawah Hitam dan kawah merah (media Thermus), serta isolat dari Kawah Putih dan Kawah Asin (media LB) dengan ukuran amplikon $\pm 1,5 \mathrm{~kb}$.

\section{DAFTAR PUSTAKA}

1. M. T. Madigan, B. L. Marrs, Extremophiles, Sci. Am., 82-87, (1997).

2. T. D. Brock, An overview of The Thermophiles. dalam Brock $\mathrm{T}$ D. Thermophiles: General, Molecular and Applied Microbiology, Jhon Wiley \& Sons, New York, 1986.
3. R. I. Amann, W. Ludwig, K. H. Schleifer, Identification of uncultured bacteria: a challenging task for molecular taxonomist, ASM News, 60: 360-365, (1994).

4. T. Desiliyarni, Analisis keragaman genetik bakteri termofilik dari Kawah Candradimuka, Pegunungan Dieng dengan teknik PCR-RFLP Gen 16S-rRNA, [Tesis], Bogor: Program Pasca Sarjana, Institut Pertanian Bogor, 1999.

5. E. C. Bottger, Approaches for identification of microorganisms, ASM News, 62: 247-250, (1996).

6. R. G. Taylor, Polymerase Chain Reaction: Basic Principles and Automation, Oxford University Press, Oxford New York, 1992.

7. Indrajaya et al., Isolasi dan identifikasi mikroorganisme termofil isolat Kawah Wayang, Jurnal Mikrobiologi Indonesia, 8: 53-56, (2003).

8. M. W. W. Adams and R. M. Kelly, Enzymes from microorganisms in extreme environments, Chemical and Engineering News (reprints), 1995. 